\title{
PROTEOMIC ANALYSIS OF SKELETAL MUSCLE AT DIFFERENT LIVE WEIGHTS IN CHAROLAIS BULLS
}

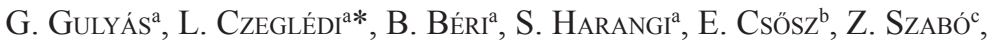 \\ T. JANÁKY ${ }^{\mathrm{c}}$ and A. JÁVOR ${ }^{\mathrm{a}}$
}

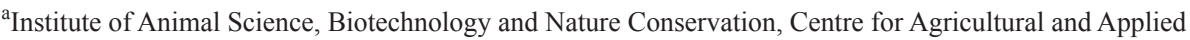
Economic Sciences, University of Debrecen, H-4032 Debrecen, Böszörményi út 138. Hungary ${ }^{b}$ Department of Biochemistry and Molecular Biology, Medical and Health Science Centre, University of Debrecen, H-4012 Debrecen, Nagyerdei körút 98 . Hungary

${ }^{\mathrm{c}}$ Department of Medical Chemistry, Faculty of Medicine, University of Szeged, H-6720 Szeged, Dóm tér 8. Hungary

(Received: 10 October, 2013; accepted: 17 January 2014)

\begin{abstract}
The aim of this study was to investigate the differences in the proteome patterns of musculus longissimus dorsi between Charolais bulls slaughtered at $500 \mathrm{~kg}$ and $700 \mathrm{~kg}$ live weight using two-dimensional difference in gel electrophoresis (2D-DIGE) and liquid chromatography-mass spectrometry (LC-MS). Three hundred fifty protein spots were visualised on gels of which 10 showed different expression levels $(\mathrm{P}<0.05)$ between groups. After mass spectrometric analysis of spots, beta-enolase (ENO3) in five different spots, alpha-enolase (ENO1), triosephosphate isomerase (TPI) in two different spots, alpha-actin (ACTA1), and heat shock protein beta-1 (HSPB1) were identified. ENO3, ENO1, TPI1, and ACTA1 had higher expression levels in bulls of $700 \mathrm{~kg}$ live weight group. ENO3, ENO1, and TPI1 are involved in energy metabolism, while ACTA1 is a structure protein in skeletal muscle. Up-regulation of heat shock protein beta-1 (HSPB1), which protein is reported to have correlation with tenderness, was observed in $500 \mathrm{~kg}$ weight group. Our result demonstrates that proteomic tools are useful in identifying markers associated with muscle development.
\end{abstract}

Keywords: 2D-DIGE, cattle, beef, slaughter weight, proteome

Beef is a significant source of animal proteins in human diet. One of the major decisions of farmers is to determine the weight of slaughter for their bulls, which depends on the special demand of market and has great influence on profitability (Holló et al., 2001). Muscle proteins determine several characteristics of meat, such as tenderness, water holding capacity, meat colour, etc. However, there is a lack in the scientific literature on cattle muscle proteome in function of live weight.

Charolais is one of the leading terminal beef breed noted for its fast growth, high quality of beef, and excellent carcass. The optimal slaughter age and weight has been long debated (ALBERTí et al., 2008). Live weight at slaughter highly depends on cattle breed and consumer demand. Slaughter weight and breed of beef cattle have effect on carcass and meat quality parameters, such as physical characteristics and structure of muscle and meat (SANUDO et al., 2004). Growth rate of cattle is positively correlated with adult body weight, high weight gain animals produce more fibres in muscle with higher glycolytic activity, which is associated with meat ageing and tenderness (JURIE et al., 1995). With advancing maturity of beef cattle, the number of less soluble collagen crosslinks also increases, leading to less tender meat

\footnotetext{
* To whom correspondence should be addressed.

Phone: +36-52-508-444/88199; fax: +36-52-486-285; e-mail: czegledi@agr.unideb.hu
} 
(Shorthose \& Harris, 1990; Weston et al., 2002), and intramuscular fat content increases with age as well (MatTin et al., 1998; BRUns et al., 2004).

Although numerous papers related to the proteomic studies on production of meat and milk, animal welfare and health (LipPolis et al., 2008; BENDIXEN et al., 2010) have been published during the last years, the application of proteomics in animal sciences is still limited. The objective of the present study was to investigate the differences in the proteome profiles of $m$. longissimus dorsi between Charolais bulls slaughtered at $500 \mathrm{~kg}$ and $700 \mathrm{~kg}$ live weight by gel based proteomics tools using fluorescent tags and mass spectrometry based protein identification.

\section{Materials and methods}

\subsection{Animals and sampling}

In a commercial beef cattle farm 10 finishing Charolais bulls were involved in the study, 5 of them were slaughtered at the live weight of $500 \mathrm{~kg}(\overline{\mathrm{x}}: 519 \mathrm{~kg}$, S.D.: $16.49 \mathrm{~kg})$ and at the age of 440 days ( $\overline{\mathrm{x}}: 445$ days, S.D.: 15.38 days) and 5 at $700 \mathrm{~kg}$ live weight ( $\overline{\mathrm{x}}: 710 \mathrm{~kg}$, S.D.: 31.58), at 540 days ( $\overline{\mathrm{x}}: 538$ days, S.D.: 43.61 days). Bulls were housed in the same barn and fed the same diet. Animals were slaughtered at a commercial slaughterhouse according to EU regulations. Table 1 shows some data of meat production traits of both groups. Musculus longissimus dorsi samples were harvested between the 12th and 13th ribs, within 30 min after slaughter. Samples were collected into cryotubes in three replicates per individual and placed into liquid nitrogen, and then were kept at $-80^{\circ} \mathrm{C}$. The three replicates of muscle samples were pooled before protein isolation.

Table 1. Means and standard deviations of beef production traits of 500 and $700 \mathrm{~kg}$ Charolais bulls

\begin{tabular}{|c|c|c|c|c|c|}
\hline & \multicolumn{2}{|c|}{$500 \mathrm{~kg}$} & \multicolumn{2}{|c|}{$700 \mathrm{~kg}$} & \multirow[b]{2}{*}{$\mathrm{P}$} \\
\hline & mean & SD & mean & SD & \\
\hline Birth weight, kg & 39.00 & 2.00 & 40.2 & 1.1 & 0.273 \\
\hline Daily gain during fattening, $\mathrm{kg}_{\text {day }}{ }^{-1}$ & 1.40 & 0.20 & 1.43 & 0.08 & 0.763 \\
\hline Ribeye area, $\mathrm{cm}^{2}$ & 99.50 & 7.05 & 126.4 & 11.55 & 0.003 \\
\hline Hot carcass weight, $\mathrm{kg}$ & 293.40 & 13.9 & 426.7 & 23.0 & 0.000 \\
\hline EUROP muscle score $(\mathrm{P}-=1$ point; $\mathrm{E}+=15$ point $)$ & 11 & 1.22 & 10.4 & 0.55 & 0.359 \\
\hline EUROP fat score $(1-=1$ point; $5+=15$ point $)$ & 5.8 & 2.2 & 4.2 & 0.45 & 0.176 \\
\hline Dressing percentage, $\%$ & 57.72 & 1.03 & 60.55 & 1.75 & 0.014 \\
\hline Bone ratio, $\%$ & 19.64 & 0.77 & 18.12 & 0.91 & 0.021 \\
\hline Meat ratio, $\%$ & 70.71 & 1.18 & 72.95 & 1.28 & 0.021 \\
\hline Meat/bone ratio & 3.60 & 0.19 & 4.02 & 0.17 & 0.006 \\
\hline Meat/fat ratio & 10.32 & 1.12 & 10.96 & 1.70 & 0.501 \\
\hline Meat production, $\mathrm{g} \mathrm{day}^{-1}$ & 469.44 & 28.31 & 558.86 & 38.42 & 0.003 \\
\hline
\end{tabular}




\subsection{Protein isolation and labelling with CyDyes}

Protein samples were prepared as follows: tissue samples were placed into liquid nitrogen and ground thoroughly to a fine powder with a mortar and pestle. The tissue powder $(50 \mathrm{mg})$ was transferred to sterile tubes containing $1 \mathrm{ml}$ of lysis buffer $\mathrm{pH} 8.5$ ( $7 \mathrm{M}$ urea, $2 \mathrm{M}$ thiourea, $4 \%(\mathrm{w} / \mathrm{v})$ CHAPS, $30 \mathrm{mM}$ Tris). The mixture was incubated for $60 \mathrm{~min}$ on ice with occasional vortexing and centrifuged at $10000 \mathrm{~g}$ for $30 \mathrm{~min}$; minimal fluorescent dye labelling (GE Healthcare) was performed according to the manufacturer's instructions.

\subsection{Two-Dimensional Difference In Gel Electrophoresis (2D-DIGE) and image analysis}

For the first dimension, $17 \mathrm{~cm}$ immobilized $\mathrm{pH}$ gradient strips ( $\mathrm{pH} 5-8$, linear, Bio-Rad) were applied. We decided to use $\mathrm{pH}$ range 5-8 as our previous tests showed the majority of proteins are located in this region. For analytical gels, a pair of $\mathrm{Cy} 3$ and $\mathrm{Cy} 5$ labelled samples (each $50 \mu \mathrm{g}$ of protein) and $50 \mu \mathrm{g}$ of Cy2 labelled internal standard were pooled, for preparative gels $600 \mu \mathrm{g}$ of unlabelled protein pool was used. Focused IPG strips were equilibrated for $10 \mathrm{~min}$ in $6 \mathrm{M}$ urea, $20 \%(\mathrm{v} / \mathrm{v})$ glycerol, $2 \%(\mathrm{w} / \mathrm{v}) \mathrm{SDS}, 50 \mathrm{mM}$ Tris $\mathrm{pH} 8.8$ and $2 \%(\mathrm{w} / \mathrm{v})$ DTT, and then for an additional $10 \mathrm{~min}$ in the same buffer except that DTT was replaced by $2.5 \%(\mathrm{w} / \mathrm{v})$ iodoacetamide.

Proteins were separated in the second dimension using Protean II XL vertical electrophoresis system (Bio-Rad). The concentration of the polyacrylamide gels was $12 \%$ $(\% \mathrm{~T})$ with $2.67 \%$ of crosslinker $(\% \mathrm{C})$. Proteins were visualized by a Molecular Imager Pharos FX Plus System (Bio-Rad). The preparative gels were stained with Coomassie BioSafe (Bio-Rad) stain according to the manufacturer's instructions.

Gels images were analyzed with Delta2D software (Decodon TM GmbH, Germany). Spots were detected, quantified, and normalized according to the volume ratio of corresponding spots detected in the Cy2 image of the pooled-sample containing internal standard using the in-gel standard warping strategy. Student's $t$-test was performed to assess the statistical significance of differentially expressed proteins at $95 \%$ confidence level ( $t$-test; $\mathrm{P}<0.05)$. For subsequent mass spectrometric analysis significant spot coordinates were transferred to Coomassie stained preparative gel for spot picking.

\subsection{Protein identification}

The protein spots of interest were cut out from the Coomassie stained gels and digested by trypsin using the in gel digestion protocol without reduction and alkylation of cysteines as described by SzABO and co-workers (2012).

Digested protein samples were analyzed on a Waters NanoAcquity UPLC system coupled with a Micromass Q-TOF Premier mass spectrometer. All acquired data were processed by the WATERS Proteinlynx GlobalServer 2.4 software using default settings. Database search was performed using Mascot 2.2 (Matrix Science, London, UK), which was set up to search Swissprot database (Swissprot 2012_05 database) assuming the digestion enzyme trypsin. Scaffold software (version 3.62, Proteome Software Inc., Portland, OR) was used to validate MS/MS based peptide and protein analysis. Protein identifications were accepted if they could be established at greater than $95.0 \%$ probability and based on at least 2 identified peptides. Protein probabilities were assigned by the Protein Prophet algorithm. 


\section{Results and discussion}

The musculus longissimus dorsi proteins in the molecular mass region from 10 to $50 \mathrm{kDa}$ and the $\mathrm{pI}$ range between 5 and 8 were included in the comparative analysis (Fig. 1). Approximately 350 spots were detected on each gel.

Ten protein spots showed differential expression levels based on normalized spot volumes between the 500 and $700 \mathrm{~kg}$ live weight groups. Nine spots showed a higher expression in the $700 \mathrm{~kg}$ weight group, while the intensity of one protein spot was higher in the $500 \mathrm{~kg}$ weight group (Fig. 2). All of the spots were identified using LC-MS method (Table 2).

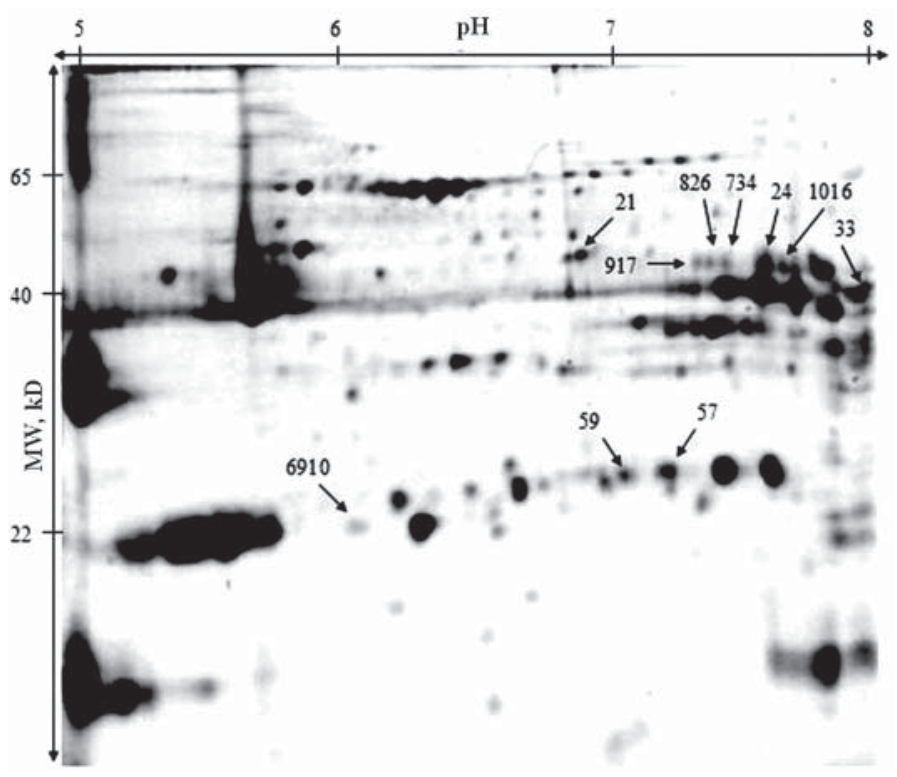

Fig. 1. Representative 2-DE DIGE image of musculus longissimus dorsi of a Charolais bull. 2-DE was performed using isoelectric focusing ( $\mathrm{pH}$ range of 5-8) in the first dimension and SDS-PAGE (12\% T, 2.67\% C) in the second

dimension. Proteins that are significantly different according to slaughter weight are marked with numbers

Spots 24, 734, 826, 917, and 1016 were all identified as beta-enolase (ENO3), in spite of that they were found at 5 different pI positions on the polyacrylamide gel. This heterogeneity might be the consequence of post-translational modifications that may influence the charge of the proteins. These modifications of beta-enolase have not been reported yet in cattle protein databases. Beta-enolase is the muscle-specific enolase, its expression greatly increased during postnatal muscle growth because enolases are involved in energy metabolism, specifically in pyruvate production (PICARD et al., 2010). The increase of muscle mass is due to an increase of muscle fibre size (TE PAs et al., 2004). The increase in muscle fibre crosssectional area from birth to 24 months is nearly linear, but the fibre number does not increase during postnatal development (WEGNER et al., 2000). This confirms our findings that 1.8-2.2fold higher beta-enolase expressions were observed in the $700 \mathrm{~kg}$ weight group. HoLLuNG and co-workers (2009) observed similar results; ENO3 was more abundant in older pigs, indicating higher glycolytic activity in older animals. 
The up-regulated protein spots in $700 \mathrm{~kg}$ weight group
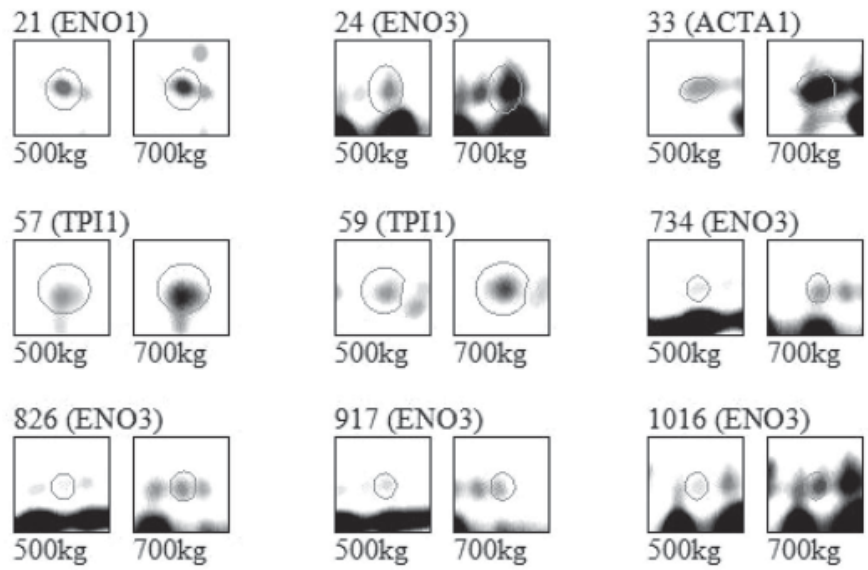

The up-regulated protein spot in $500 \mathrm{~kg}$ weight group

6910 (HSPB1)

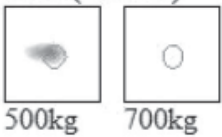

Fig. 2. Differences in protein expression between 500 and $700 \mathrm{~kg}$ live weight groups of Charolais bulls

Table 2. Differentially expressed proteins $(\mathrm{P}<0.05)$ of 500 and $700 \mathrm{~kg}$ Charolais bulls according to slaughter weight identified by LC-MS

\begin{tabular}{|c|c|c|c|c|c|}
\hline Spot & Identified protein & Accession number & $\mathrm{N} / \mathrm{C}^{1}$ & $\mathrm{pI} / \mathrm{Mw}(\mathrm{Da})^{2}$ & Ratio $^{3}$ \\
\hline 33 & Actin, alpha skeletal muscle & P68138 (Bos taurus) & $15 / 57$ & $5.2 / 42,051$ & 1.6 \\
\hline 1016 & Beta-enolase & Q3ZC09 (Bos taurus) & $3 / 13$ & $7.6 / 47,096$ & 1.8 \\
\hline 24 & Beta-enolase & Q3ZC09 (Bos taurus) & $5 / 20$ & $7.6 / 47,096$ & 1.9 \\
\hline 734 & Beta-enolase & Q3ZC09 (Bos taurus) & $10 / 23$ & $7.6 / 47,096$ & 2.2 \\
\hline 826 & Beta-enolase & Q3ZC09 (Bos taurus) & $10 / 31$ & $7.6 / 47,096$ & 2.3 \\
\hline 917 & Beta-enolase & Q3ZC09 (Bos taurus) & $15 / 51$ & $7.6 / 47,096$ & 2.2 \\
\hline 21 & Alpha-enolase & Q9XSJ4 (Bos taurus) & $24 / 64$ & $6.4 / 47,326$ & 1.4 \\
\hline 57 & Triosephosphate isomerase & Q5E956 (Bos taurus) & $9 / 49$ & $6.3 / 26,690$ & 1.7 \\
\hline 59 & Triosephosphate isomerase & Q5E956 (Bos taurus) & $16 / 80$ & $6.3 / 26,690$ & 1.8 \\
\hline 6910 & Heat shock protein beta- 1 & Q3T149 (Bos taurus) & $9 / 70$ & $6.0 / 22,393$ & 0.4 \\
\hline
\end{tabular}

${ }^{1}$ : Number of matched peptides/sequence coverage percentage $(\%) ;{ }^{2}$ : theoretical isoelectric point and molecular weight; ${ }^{3}$ : ratio value of the 700 - to $500-\mathrm{kg}$ weight group 
The enolase has three major isoforms, beside beta-enolase, alpha-enolase (ENO1) has also showed an increased expression in 700-kg live weight animals. A transition occurs from $\alpha \alpha$ isoform (ENO1) toward $\beta \beta$ (ENO3) during ontogenesis in skeletal muscle (KeLLER et al., 1994). Previous studies have demonstrated that the level of alpha enolase does not increase with aging. In contrast with skeletal muscle, the glycolitic enzymes (including ENO1) show increasing expression level with aging in heart tissue (LEE et al., 2002).

An additional protein was identified, which is included in the group of metabolic proteins as well. Triosephosphate isomerase (TPI1) was observed at two different pI positions (spot 57, 59). Two types of posttranslational modifications of TPI1 were reported until now, both phosphorylation and acetylation decrease the pI of proteins. In our study we have not investigated which modifications might be responsible for the differences observed in $\mathrm{pI}$. Protein spots 57 and 59 had 1.7-fold and 1.8-fold higher expression in the 700-kg weight bulls compared to the $500-\mathrm{kg}$ weight bulls, respectively. It may indicate that the different expression levels of this protein are related to muscle growth. TPI1 plays an important role in energy production, being an enzyme that catalyzes the reversible interconversion of the dihydroxyacetone phosphate and D-glyceraldehyde 3-phosphate in glycolysis (AlBERY \& KNOWLES, 1976). Positive correlation was found between the triosephosphate isomerase level and age (Hollung et al., 2009).

One of the 10 identified proteins is a structural protein. Alpha actin (spot No. 33) is a major constituent of the contractile apparatus in skeletal muscle. In Charolais bulls, the expression level of alpha actin was 1.6-fold higher in the 700-kg weight group compared to the 500-kg weight group. TE PAs et al. (2004) found a significant increase of muscle fibre size between 14- and 18-month-old animals, that change could be a consequence of the increasing number of contractile proteins within the muscle fibre.

Up-regulation of heat shock protein beta-1 (Hsp27) was observed in 500-kg weight group. Hsp27 is a member of small heat shock proteins, main cellular functions are chaperone activity, regulation of the actin cytoskeleton, and control of apoptosis (GuSEv et al., 2002). Previous papers have reported lower Hsp27 level in beef with greater tenderness (KIM et al., 2008). The tenderness variation depends on the chronological age of the cattle at slaughter. One may assume that the meat of 440-day old bulls are more tender than 540-day-old one's, as younger animals are more tender than older animals (WeBB et al., 1964). The change in tenderness with increasing age is due to the less soluble collagen crosslink (WESTON et al., 2002), as solubility of collagen decreases markedly between 12 and 16 months in bulls (BocCARD et al., 1979).

\section{Conclusions}

In conclusion, based on our 2D-DIGE proteomic analysis of $m$. longissimus dorsi in Charolais bulls, 10 protein spots were differentially expressed $(\mathrm{P}<0.05)$ between two live weight groups of animals, such as $500 \mathrm{~kg}$ and $700 \mathrm{~kg}$. Furthermore, through mass spectrometric analysis, we identified five proteins (ENO3, ENO1, TPI1, ACTA1, and HSPB1) that were related to the investigated trait. These proteins could influence animal performance and product quality as they play a role in energy metabolism and production, contractile apparatus and its regulation in the cell. Future work should focus on the dynamics of expression profiles in a wider range of live weight. 
The work was supported by the TÁMOP-4.2.1/B-09/1/KONV-2010-0007 and TÁMOP-4.2.2/B-10/1-2010-0024 projects. The project is co-financed by the European Union and the European Social Fund. Part of work was done at the Proteomics Core Facility, University of Debrecen and was supported by KMA 0149/3.0 grant.

\section{References}

Albertí, P., Panea, B., Sañudo, C., Olleta, J.L., Ripoll, G., Ertbjerg, P., Christensen, M., Gigli, S., Failla, S., Concetti, S., Hocquette, J.F., Jailler, R., Rudel, S., Renand, G., Nute, G.R., Richardson, R.I. \& Williams, J.L. (2008): Live weight, body size and carcass characteristics of young bulls of fifteen European breeds. Livestock Sci., 114, 19-30.

Albery, W.J. \& KNowles J.R. (1976): Free-energy profile for the reaction catalyzed by triosephosphate isomerase. Biochemistry, 15, 5627-5631.

Bendixen, E., Danielsen, M., Hollung, K., Gianazza, E. \& Miller, I. (2010): Farm animal proteomics - A review. J. Proteomics, 74, 282-293.

Boccard, R.L., Naudé, R.T., Cronje, D.E., Smit, M.C., Venter, H.J. \& Rossouw, E.J. (1979): The influence of age, sex and breed of cattle on their muscle characteristics. Meat Sci., 3, 261-280.

Bruns, K.W., Pritchard, R.H. \& Boggs, D.L. (2004): The relationships among body weight, body composition, and intramuscular fat content in steers. J. Anim. Sci., 82, 1315-1322.

Gusev, N.B., Bogatcheva, N.V. \& Marston S.B. (2002): Structure and properties of small heat shock proteins (sHsp) and their interaction with cytoskeleton proteins. Biochemistry (Moscow), 67, 511-519.

Holló, G., Csapó J., TöZsér J., Holló I. \& SzŰcs E. (2001): Effect of breed, live weight on the fatty acid, amino acid content and on the biological value of beef. Acta Alimentaria, 30, 313-322.

Hollung, K., Grove, H., Færgestad, E.M., Sidhu, M.S. \& Berg, P. (2009): Comparison of muscle proteome profiles in pure breeds of Norwegian Landrace and Duroc at three different ages. Meat Sci., 81, 487-492.

Jurie, C., Robelin, J., Picard, B., Renand, G. \& Geay, Y. (1995): Inter-animal variation in the biological characteristics of muscle tissue in male limousine cattle. Meat Sci., 39, 415-425.

Keller, A., Berod, A., Dussaillant, M., Lamande, N., Gros, F. \& Lucas, M. (1994): Coexpression of alpha and gamma enolase genes in neurons of adult rat brain. J. Neurosci. Res., 38, 493-504.

Kim, N.K., Cho, S., Lee, S.H., Park, H.R., Lee, C.S., Cho, Y.M., Choy, Y.H., Yoon, D., Im, S.K. \& Park, E.W. (2008): Proteins in longissimus muscle of Korean native cattle and their relationship to meat quality. Meat Sci., 80, 1068-1073.

Lee, C.K., Allison, D.B., Brand, J., Weindruch, R. \& Prolla, T.A. (2002): Transcriptional profiles associated with aging and middle age-onset caloric restriction in mouse hearts. P. Natl Acad. Sci. USA, 99, 14988-14993.

Lippolis, J.D. \& Reinhardt, T.A. (2008): Centennial Paper: Proteomics in animal science. J. Anim. Sci., 86, 2430 2441.

Maltin, C.A., Sinclair, K.D., Warriss, P.D., Grant, C.M., Porter, A.D., Delday, M.I. \& Warkup, C.C. (1998): The effects of age at slaughter, genotype and finishing system on the biochemical properties, muscle fibre type characteristics and eating quality of bull beef from suckled calves. Anim. Sci., 66, 341-348.

Picard, B., Berri, C., Lefaucher, L., Molette, C., Sayd, T. \& Terlouw, C. (2010): Skeletal muscle proteomics in livestock production. Brief. Funct. Genomics, 9, 259-278.

Sanudo, C., Macie, E.S., Olleta, J.L., Villarroel, M., Panea, B. \& Alberti P. (2004): The effects of slaughter weight, breed type and ageing time on beef meat quality using two different texture devices. Meat Sci., 66, 925-932.

Shorthose, W.R. \& Harris, P.V. (1990): Effect of animal age on the tenderness of selected beef muscles. J. Food Sci., 55, 1-8.

Szabo, Z., Szeline Szomor, J., Foeldi, I. \& Janaky, T. (2012): Mass spectrometry-based label free quantification of gel separated proteins. J. Proteomics, 75(18), 5544-5553.

te Pas, M.F.W., Everts M.E. Haagsman H.P. (Eds.) (2004): Muscle development of livestock animals: physiology, genetics, and meat quality. CABI, Cambridge, USA. pp. 2-7.

Webb, N.B., Kahlenberg, O.J. \& Naumann, H.D. (1964): Factors influencing beef tenderness. J. Anim. Sci., 23, 1027-1031.

Wegner, J., Albrecht, E., Fiedler, I., Teuscher, F., Papstein, H J. \& Ender, K. (2000): Growth- and breed-related changes of muscle fiber characteristics in cattle. J. Anim. Sci., 78, 1485-1496.

Weston, A.R., Rogers, R.W. \& Althen, T.G. (2002): The role of collagen in meat tenderness. Prof. Anim. Scientist, 18, 107-111.

Acta Alimentaria 44, 2015 